\title{
Microbiological and physicochemical characterization of surimi obtained from waste of piramutaba fillet
}

\author{
Caracterização físico-química e microbiológica de surimi obtido de resíduos da filetagem de piramutaba
}

\author{
Giane Célia dos Santos GALVÃO ${ }^{1}$, Lúcia de Fátima Henriques LOURENÇO ${ }^{1}$, \\ Suezilde da Conceição Amaral RIBEIRO ${ }^{2,3}$, Carmelita de Fátima Amaral RIBEIRO ${ }^{3,4 *}$, \\ Kil Jin PARK ${ }^{4}$, Eder Augusto Furtado ARAUJO ${ }^{1}$
}

\begin{abstract}
The aim of this work was to perform the microbiological and physicochemical characterization of surimi made from waste of piramutaba filleting. The results of physicochemical characterization of the waste and surimi were: moisture (76.37 and 79.11\%), total lipids (5.35 and 0.74\%), proteins (14.92 and 10.79\%), ash (3.03 and 2.35\%), $\mathrm{pH}$ (6.9 and 7.4), caloric value (109.15 and $77.86 \mathrm{kcal}^{-1} \mathrm{~g}^{-1}$ ), and water activity (both 0.98$)$, respectively. The results of the levels of total volatile bases were $7.29 \mathrm{mgN} / 100^{-1} \mathrm{~g}$ (waste) and $7.01 \%$ carbohydrate (surimi). The values of total lipids and proteins were reduced during the preparation of surimi, probably due to successive washes during the processing. Waste and surimi were examined microbiologically and are in compliance with required parameters. The results show a loss of red ( $a^{\star}$ parameter) and yellow ( $b^{\star}$ parameter) color. On the other hand, the $\mathrm{L}^{\star}$ parameter (lightness) increased after the processing of surimi. It can be concluded that piramutaba waste can be used for surimi preparation and as a source of nutrients for human consumption, providing an alternative use of these wastes avoiding their disposal polluting the environment.
\end{abstract}

Keywords: surimi; wastes; microbiological quality; physicochemical characterization.

\section{Resumo}

O objetivo deste trabalho foi realizar a caracterização físico-química e microbiológica do surimi obtido de resíduos da filetagem de piramutaba. Os resultados da caracterização físico-química dos resíduos e surimi foram: umidade (76,37 e 79,11\%), lipídios totais (5,35 e 0,74\%), proteínas (14,92 e 10,79\%), cinzas (3,03 e 2,35\%), pH (6,9 e 7,4), valor calórico (109,15 e 77,86 kcal.g - $^{-1}$ e atividade de água (ambos 0,98), respectivamente. Os resultados dos valores de bases voláteis totais foi de $7,29 \mathrm{mgN} / 100^{-1} \mathrm{~g}$ (resíduos) e carboidratos de $7,01 \%$ (surimi). Os valores de lipídios totais e proteínas foram reduzidos durante o preparo do surimi, provavelmente, devido a sucessivas lavagens durante o processamento. Os resíduos e o surimi foram analisados microbiologicamente estando em conformidade com os parâmetros exigidos. Os resultados mostraram que houve uma perda da cor vermelha (parâmetro $a^{*}$ ) e amarela (parâmetro $b^{\star}$ ). Por outro lado, o parâmetro $L^{\star}($ luminosidade) aumentou após o processamento do surimi. Conclui-se que os resíduos de piramutaba podem ser empregados como matéria-prima de qualidade na elaboração de surimi e como fonte de nutrientes para a alimentação humana, constituindo-se também como uma alternativa para destino dos resíduos, antes lançados no ambiente.

Palavras-chave: surimi; resíduos; qualidade microbiológica; caracterização físico-química.

\section{Introduction}

One of the most significant groups of ichthyofauna in the Amazonian biodiversity is the large migratory catfish belonging to the family Pimelodidae and some have high commercial value, for example golden piraiba, jaú, surubim caparari, and piramutaba.

Piramutaba (Brachyplatystoma vaillantii) belonging to the siluriformes order, is one of the species caught in the Amazon estuary and is very important for regional, national, and international economy. Over 30,000 $t$ of this species are sold annually in the Amazon (BRASIL, 2005). According to Pinheiro and Frédou (2004), among the fishes landed in the state of Pará, from the estuary, piramutaba is the main target of industrial fisheries.

According to Feltes et al. (2010), the industrial fish processing operations generate a significant amount of wastes, which are rich in proteins and long-chain fatty acids, among which the unsaturated omega-3 fatty acids are prominent. Fish wastes can be used as a substrate for the production of texturized proteins, protein concentrate, mechanically deboned meat, surimi, reestructured products, or oil used for human feeding even. On the other hand, according to Godoy et al. (2010), technological alternatives with aggregate value that

\section{Received 30/07/2010}

Accepted 28/02/2012 (004945)

${ }^{1}$ Faculty of Food Engineering, Federal University of Pará - UFPA, Av. Perimentral, s/n, Guamá, CEP 660000-00, Belém, PA, Brasil

2 Department of agribusiness, Federal Office for Education, Science and Technology of Pará - IFPA, BR 316, KM 62, CEP 687409-70, Castanhal, PA, Brasil

3 Center for Natural Science and Technology, State University of Pará - UEPA, Trav. Enéas Pinheiro, Marco, CP 2626, CEP 66095-100, Belém, PA, Brasil,

e-mail: carmelribeiro@yahoo.com.br

${ }^{4}$ Faculty of Agricultural Engineering, State University of Campinas - UNICAMP, CP 6011, CEP 13083-875, Campinas, SP, Brasil

${ }^{*}$ Corresponding author 
allow the of the fish waste management can generate jobs, promote sustainable development, and contribute to the fight against hunger.

The utilization of fish waste in food industries and tanneries is recent in the country, and it has been an alternative solution to industrialization waste disposal minimizing the impact on the environment. The main waste from piramutaba filleting consists of the head, scales, skin, viscera, and carcass represents more than $60 \%$ of its production and can be used in the manufacture of various food products, among them surimi. The use of edible wastes from traditional operations of piramutaba filleting is of great importance for the industry since their wastes, when used for human consumption, not only provide extra income, but also minimize environmental pollution problems (INSTITUTO..., 1999).

According to Kuhn et al. (2008), surimi is a product obtained from the fish muscle, and it consists of soluble proteins in salt solutions, especially myofibrillar proteins, which can be extracted from mechanically separated fish meat in the early stage of the process, forming a concentrate with high nutritional quality and excellent functional properties. This protein concentrate has been used for centuries in Japan to produce kamaboko products, which are thermostable gels formed during the heating of surimi, which had been previously treated with salt to solubilize its protein

According to Peixoto, Sousa and Mota (2002), the production of surimi has been contributing to a better utilization of available fishery resources, including the accompanying fauna, consisting in the transformation of a protein source of high biological value, which normally would be destined for animal feed in the fishmeal form, in products of high nutritional value and technological quality suitable for human consumption. According to Martín-Sánchez et al. (2009), the processing of surimi is an effective way to take advantage of under-used species of fish by making a more sustainable and profitable use of resources.

The aim of this study was to perform the microbiological and physicochemical characterization of the surimi made from waste of piramutaba filleting.

\section{Material and methods}

\subsection{Wastes}

Wastes from Piramutaba (Brachyplatystoma vaillantii) industrial filleting were obtained in the fishery industry Campasa S.A and Pesqueira Maguary, located in the cities of Curuçá and Belém, Pará state. The wastes were collected immediately after removal from the fish at the fillet processing, washed with chlorinated water $(5 \mathrm{ppm})$, packed in plastic bags, frozen at $-18^{\circ} \mathrm{C}$, and transported to the Federal University of Pará in Styrofoam boxes with ice, where they were stored in a freezer at $-21^{\circ} \mathrm{C}$.

\subsection{Processing of piramutaba surimi}

Preparation of surimi was carried out according to methodology described by Gonçalves, Nogueira and Lourenço (2009), with some modifications (Figure 1).

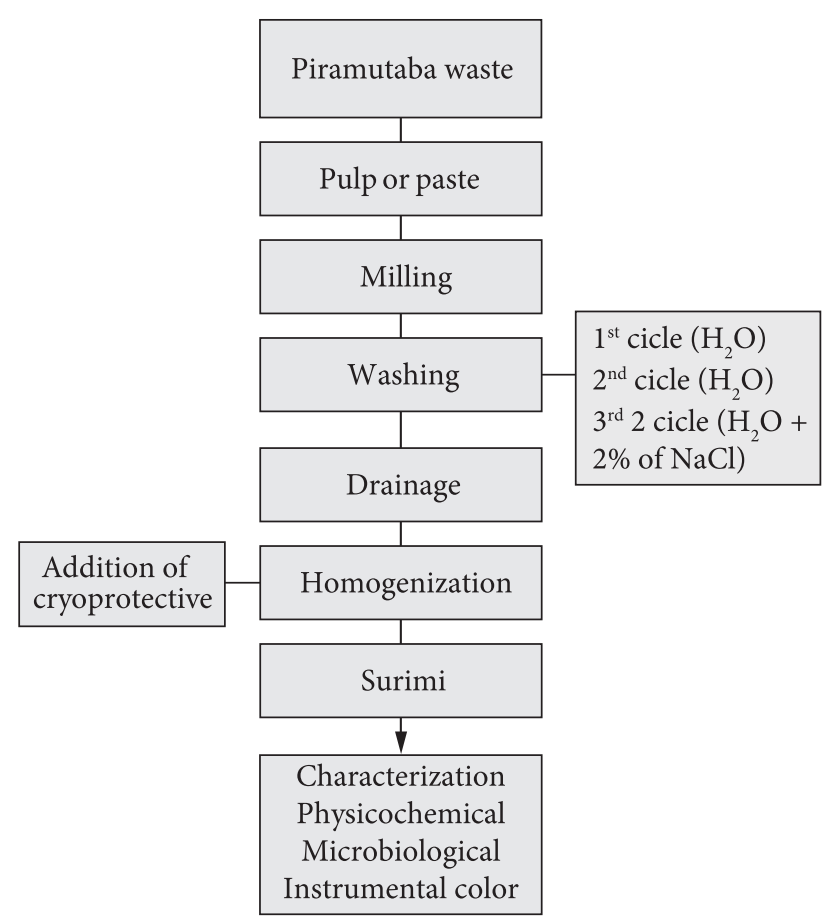

Figure 1. Flowchart of the surimi processing steps.

Piramutaba wastes (frozen) were crushed using a WALITTA Master R17633 food processor. The mass obtained was washed (three cycles) with potable water at a 10 minutes interval with slow manual shaking followed by 5 minutes for decanting. In the washing step, the first two washes were carried out with water only, and the third was carried out by adding $2 \% \mathrm{NaCl}$ in relation to the amount of pulp to help the extraction of water-soluble proteins. The water:pulp ratio was 5:1, and part of the water was used as ice to keep the temperature between 4 and $5{ }^{\circ} \mathrm{C}$. Drainage was done using a centrifuge to remove the excess of water. Subsequently, cryoprotectives, sodium tripolyphosphate $(0.2 \%)$, and sorbitol (4\%) were added to the mass and mixed in a cutter homogenizer for 5 minutes.

The company Duas Rodas Industrial Ltda provided the cryoprotectives additives used in the surimi preparation: sodium tripolyphosphate and sorbitol.

\subsection{Physicochemical characterization}

Carried out in triplicate, the physicochemical characterization of the raw material and surimi included: moisture, total lipids (Soxhlet method), protein (Kjeldahl method), ash (oven at $550^{\circ} \mathrm{C}$ - QUIMIS model Q318 M 24), pH, water activity (Aqualab Series 3 TE of Decagon) carbohydrates (only in surimi), and caloric value in accordance with the analytical standards of the AOAC (ASSOCIATION..., 1997). Equations 1 and 2, respectively, determined the carbohydrate and caloric value.

$$
\begin{aligned}
& \mathrm{E}=100-(\mathrm{A}+\mathrm{B}+\mathrm{C}+\mathrm{D}) \\
& \mathrm{Cv}=(\mathrm{P} \times 4)+(\mathrm{C} \times 4)+(\mathrm{L} \times 9)
\end{aligned}
$$


where: A - total protein (\%), B - lipids (\%), C - moisture (\%), D - ash (\%), Cv - caloric value (kcal), P - protein (\%), C - carbohydrates (\%), and L - lipids (\%).

To determine the fish freshness, an analysis of total volatile bases (TVB) in the fish waste was carried out (BRASIL, 1952).

\subsection{Microbiological analysis}

Microbiological determinations were carried out in the waste and surimi, according to the standards required by national legislation (BRASIL, 2001) for coliforms at $45^{\circ} \mathrm{C}$, coagulase-positive staphylococci, and Salmonella spp. In addition, Clostridium sulfite reducer count was made only for surimi. All analysis followed the methodology described by Vanderzant and Splittstoesser (1992).

\subsection{Instrumental measures of color}

To verify the instrumental color of piramutaba waste and surimi, the readings were carried out in triplicate using a portable colorimeter MINOLTA CR 310 obtaining the $\mathrm{L}^{*}$ (lightness), $\mathrm{a}^{*}$ (red intensity) and $\mathrm{b}^{*}$ (yellow intensity) parameters.

The colorimeter emits a light beam which passes through the sample and comprises three distinct color coordinates, $\mathrm{L}^{*}$, $\mathrm{a}^{*}$ and $\mathrm{b}^{*}$, and each one is directed to a photosensor coupled to a specific optical filter. The representation of $L^{*}, a^{*}$ and $b^{*}$ corresponds to human vision, perception, and interpretation of color differences. In this representation, $\mathrm{L}^{\star}$ indicates the brightness factor and $\mathrm{a}^{\star}$ and $\mathrm{b}^{\star}$ are chromaticity coordinates used in mathematical expressions. The result expresses the variation of color $(\Delta \mathrm{E})$ given by Equation 3 .

$\Delta E^{*}=\left[\left(\Delta L^{*}\right)^{2}+\left(\Delta a^{*}\right)^{2}+\left(\Delta b^{*}\right)^{2}\right]^{1 / 2}$

\section{Results and discussion}

\subsection{Physicochemical characterization}

The results of the physicochemical characterization of piramutaba wastes and surimi (in wet basis) are presented in Table 1.

Values of moisture, fat, protein, and ashes of piramutaba waste shown in Table 1 are different from the data of Gonçalves, Nogueira and Lourenço (2009) and Bentes et al. (2009), who found the moisture content of 78.63 and $80.30 \%$, proteins 16.12 and $18,47 \%$, lipids 1.05 and $0.43 \%$ and ashes 0.64 and $1.01 \%$, respectively. However, both studies were conducted with piramutaba muscle, while the present analysis was carried out with the filleting waste. Gonçalves, Nogueira and Lourenço (2009) found the caloric value of $87.17 \mathrm{kcal}$ piramutaba for waste, which is much smaller value than that found in this study. The chemical composition of fish can vary with the tissues, organs, sex, age, season, and gonadal development.

The average $\mathrm{pH}$ value of wastes was equal to that found by Peixoto, Sousa and Mota (2002) for Macrodon ancylodon, and it is within the limits considered acceptable for fresh fish. The
Regulation of Industrial and Sanitary Inspection of Animal Products - RIISPOA (BRASIL, 2001) establishes as a maximum $\mathrm{pH}$ of 6.5 for the fresh fish muscle; however it is known that the $\mathrm{pH}$ increase in muscle may be related to autolysis and subsequent bacterial contamination.

The average value of water activity of piramutaba waste was 0.98 at temperature of $25^{\circ} \mathrm{C}$, a result considered suitable to pathogenic bacteria development, which occurs in an optimum range between 0.995 and 0.980 (CARRASCOSA; CORNEJO, 1989). Simões et al. (2007) found water activity of 0.983 for the Nile tilapia and high moisture content.

The average content of TVB-N $\left(7.29 \mathrm{mgN} / 100^{-1} \mathrm{~g}\right)$ found in piramutaba waste was below the established limit by Brazilian law, $30 \mathrm{mgN} / 100^{-1} \mathrm{~g}$ (BRASIL, 1952). The TVB determination in fish, although is used in the evaluation of freshness, is a cause of controversy among researchers, especially regarding the limits of product acceptance. The value of $30 \mathrm{mgN} / 100^{-1} \mathrm{~g}$ has proved compatible with other evaluation parameters thus leading some countries, including Brazil, to adopt this value as an upper limit for sale of fish (TEODORO; ANDRADE; MANO, 2007).

With regard to piramutaba surimi, it can be seen in Table 1 that there was an increase in moisture contents (79.11\%) and a reduction in the total lipids levels $(0.74 \%)$, protein $(10.79 \%)$, and ash $(2.35 \%)$, probably caused by successive washes during the processing. Mello et al. (2010) found similar values of moisture (80.82\%), protein $(14.6 \%)$, lipids $(0.27 \%)$, and ash $(0.98 \%)$ for tilapia surimi.

The protein content found in piramutaba surimi (10.78\%) was also close to the levels found by Peixoto, Sousa and Mota (2002) for Macrodon ancylodon (11.63\%) and Silva (2006), who analyzed mechanically separated meat of weakfish (13.78\%) and rosy catfish (15.44\%).

According to Peixoto, Sousa and Mota (2002), during the processing of surimi, part of the fat is extracted, and the myofibrillar proteins are concentrated resulting in a product with low fat and cholesterol content. Karthikeyan, Dileep and Shamasundar (2006) report that after the processing of surimi, normally, there is a decreased protein content and increased moisture content due to washing of fish flesh.

Table 1. Physicochemical characterization of wastes and piramutaba surimi.

\begin{tabular}{lcc}
\hline \multicolumn{1}{c}{ Analyses } & Wastes & \multicolumn{1}{c}{ Surimi } \\
\hline Moisture \% & $76.37 \pm 0.88$ & $79.11 \pm 0.64^{*}$ \\
Total lipids \% & $5.35 \pm 0.19$ & $0.74 \pm 0.07^{*}$ \\
Proteins \% & $14.92 \pm 1.13$ & $10.79 \pm 0.28^{*}$ \\
Ash \% & $3.03 \pm 0.07$ & $2.35 \pm 0.36^{*}$ \\
$\mathrm{pH}$ & $6.9 \pm 0.06$ & $7.4 \pm 0.02^{\star}$ \\
Carbohydrates $(\%)$ & - & 7.01 \\
Caloric value $\left(\mathrm{kcal}^{-\mathrm{g}^{-1}}\right)$ & $109.15 \pm 0.16$ & $77.86 \pm 0.12$ \\
Total volatile bases $\left(\mathrm{mgN} / 100^{-1} \mathrm{~g}\right)$ & $7.29 \pm 0.06$ & - \\
$\mathrm{A}_{\mathrm{w}}$ & 0.98 & 0.98 \\
\hline
\end{tabular}

*The results are averages of three determinations. 
The piramutaba surimi showed an increase in $\mathrm{pH}$ value, reaching 7.4. According to Balange et al. (2009), during the washing step in the processing of surimi, acid compounds, especially lactic acid, can be leached out, which may have led to this increase in surimi's $\mathrm{pH}$.

The fish has intrinsic conditions that favor microbial multiplication reducing the shelf-life of the product, which can be a concern to public health. The high water activity, the chemical composition, the content of unsaturated fats easily prone to oxidation, and the almost neutral $\mathrm{pH}$ of fish meat are decisive factors to stimulate the growth of microorganisms (OLIVEIRA et al., 2008).

\subsection{Microbiological analysis}

The microbiological analysis of piramutaba wastes and surimi samples are presented in Table 2.

The results of coliforms at $45^{\circ} \mathrm{C}$, Salmonella, and coagulase positive Staphylococci indicate that the samples of waste and piramutaba surimi were within the limits established by legislation (BRASIL, 2001).

The presence of coliforms in processed foods is considered a useful indication of post- sanitizing contamination evidencing poor hygiene and sanitation practices, which do not meet the required recommendations for food processing. (LIBRELATO; LOPES-SHIKIDA, 2005). According to Cunha Neto, Silva and Stamford (2002), the hygiene condition in which food is prepared is one of the factors responsible for the growth of microorganism.

The presence of Salmonella spp. in food indicates inadequacy of the product for consumption, and the bacteria of this genus are the main responsible for food-borne poisoning outbreaks (MAGNANI et al., 2000). Therefore, the samples analyzed in this study are suitable for consumption.

Mello et al. (2010) evaluated four batches (collected at two-month intervals) containing pulp and tilapia surimi In the first batch of pulp and surimi, coagulase positive Staphylococcus were detected as well as E. coli in the pulp. In the second batch, although $E$. coli has not contaminated it, contamination by coagulase positive Staphylococcus persisted and was even verified the presence of Salmonella spp.. Samples of third and fourth batches met the standards established by Brazilian legislation for surimi and similar.

Jesus, Edson Lessi and Tenuta-Filho (2001) studied chemical and microbiological stability of minced fish products of several species of Amazonian fish during 150 days of storage in a freezer $\left(-18 \pm 1{ }^{\circ} \mathrm{C}\right.$ and $\left.-36 \pm 1{ }^{\circ} \mathrm{C}\right)$. During this experimental period, the samples remained good for consumption. According to Germano and Germano (2003), foods with high moisture content and a high percentage of protein, such as fish, are frequently involved in staphylococcal food poisoning outbreaks.

Fish is very prone to contamination and decomposition; therefore, during its preparation, adequate sanitation conditions are essential to ensure it is safe to consume, following microbiological standards set by the federal agencies to avoid risks to consumer health (VAZ, 2005).

\subsection{Color analysis}

The average values obtained in the color analysis by CIE $\mathrm{L}^{*}, \mathrm{a}^{*}$, and $\mathrm{b}^{*}$ system carried out in the samples of piramutaba waste and surimi are shown in Table 3 .

It seems that there was a great variation in surimi color when evaluated according to the calculation of $\Delta \mathrm{E}^{\star}$. In of $\mathrm{a}^{\star}$ and $\mathrm{b}^{*}$ analysis, in which the color red and yellow are evaluated, respectively, the reduction in these values shows that there was a major loss of red and yellow color in the surimi, probably due to the high loss of blood pigments and carotenoids (responsible for the reddish color of the fish) removed during the wash steps of the waste. Vaz (2005) found higher values of $a^{*}(0.29)$ and $b^{*}$ (12.84) in tilapia surimi.

The values obtained for the $L^{\star}$ parameter was higher in the surimi, i.e., the product had a lighter color than that of the wastes. According to Sarmiento (2006), higher values of lightness $\left(\mathrm{L}^{*}\right)$ indicate a clear coloration of meat, which is usually desired by consumers since the browning of meat is usually associated with deterioration. Ribeiro (2007) found different values for color in mapará fillets, $69.82 \%$, which presented lowest brightness,

According to Chawla, Venugopal and Nair (1996) and Vaz (2005), during the washing of fish muscle, the carotenoids, pigments in blood, and soluble nitrogen compounds are removed resulting in less intense color and remarkable odor

Table 3. Results of color analysis of piramutaba waste and surimi.Values are mean \pm standard deviation.

\begin{tabular}{lrr}
\hline \multicolumn{1}{c}{ Parameters } & \multicolumn{1}{c}{ Wastes } & \multicolumn{1}{c}{ Surimi } \\
\hline Luminosity $\left(\mathrm{L}^{*}\right)$ & $73.91 \pm 0.14$ & $87.48 \pm 0.27$ \\
Intensity of red $\left(\mathrm{a}^{\star}\right)$ & $7.23 \pm 0.55$ & $0.07 \pm 0.05$ \\
Intensity of yellow $\left(\mathrm{b}^{\star}\right)$ & $13.79 \pm 0.12$ & $5.76 \pm 0.20$ \\
Change color $\left(\Delta \mathrm{E}^{\star}\right)$ & $75.53 \pm 0.58$ & $87.66 \pm 0.34$ \\
\hline
\end{tabular}

The results are averages of three determinations.

Table 2. Microbiological analysis of piramutaba wastes and surimi.

\begin{tabular}{|c|c|c|c|}
\hline Analyses & Wastes & Surimi & Legislation \\
\hline Coliforms at $45^{\circ} \mathrm{C}\left(\mathrm{MPN} \cdot \mathrm{g}^{-1}\right)^{* *}$ & 93 & 95 & $\operatorname{Max} 10^{2}$ \\
\hline Salmonella (25g) & Absence & Absence & Absence \\
\hline Staphylococci Coagulase $+\left(\mathrm{UFC} \mathrm{g}^{-1}\right)^{\star * *}$ & $<1 \times 10$ & $<1.0 \times 10$ & $\operatorname{Max} 10^{3}$ \\
\hline Clostridium sulfite reducer & - & Negative & - \\
\hline
\end{tabular}

${ }^{*}$ NNP: most probable number; ${ }^{* *}$ UFC: colony forming unit. 
reduction in the minced meat. Moreover, the brighter the surimi, the faster it will be marketed. According to Ogawa and Maia (1999), myoglobin (Mb), together with small concentrations of hemoglobin $(\mathrm{Hb})$, is the main pigment responsible for the brown-red coloration of fish meat.

According to Carvalho (2005), the process of washing is necessary in the manufacture of surimi due to the following reasons: it inhibits protein denaturation due to freezing because theoretically this mechanism of protein denaturation is caused by crioconcentration of salts in present the muscle; it eliminates the soluble proteins of the fish meat; it removes several components that may possibly lead to denaturation of proteins during freezing such as enzymes and volatile bases; it removes blood, muscular pigments, and meat lipids that darken the surimi.

\section{Conclusions}

The values of total lipids and proteins were reduced during the preparation of surimi, probably due to successive washes required in this process. Waste of piramutaba fillet and its surimi were examined microbiologically, and the results are in compliance with the required parameters. It was concluded that piramutaba waste can be used for surimi preparation and as a source of nutrients for human consumption, providing an alternative use of these wastes avoiding their disposal polluting the environment.

\section{Acknowledgements}

The authors are grateful for the financial support provided by CAPES.

\section{References}

ASSOCIATION OFFICIAL ANALYTICAL CHEMIST - AOAC. Official methods of analysis. 16. ed., 3rd rev. Washington: AOAC, 1997.

BALANGE, A. K. et al. Gel strengthening effect of wood extract on surimi produced from mackerel stored in ice. Journal of Food Science, v. 74, n. 8, 2009. PMid:19799658. http://dx.doi.org/10.1111/ j.1750-3841.2009.01322.x

BENTES, A. S. et al. Caracterização física e química e perfil lipídico de três espécies de peixes amazônicos. Revista Brasileira de Tecnologia Agroindustrial, v. 3, n. 2, p. 97-108, 2009.

BRASIL. Ministério da Agricultura, Pecuária e Abastecimento. Regulamento da Inspeção Industrial e Sanitária de Produtos de Origem Animal - RIISPOA. Aprovado pelo Decreto no 30.691, 29 de março de 1952, alterado pelos Decretos no 1255 de 25 de junho de $1962, \mathrm{n}^{\circ} 1236$ de 02 setembro de $1994, \mathrm{n}^{\circ} 1812$ de 08 de fevereiro de 1996 e nº 2244 de 04de junho de 97. Diário Oficial da República Federativa do Brasil, Brasília, DF, mar. 1952. 165 p.

BRASIL. Ministério da Saúde, Agência Nacional de vigilância Sanitária - ANVISA. Resolução RDC nº 12, de 02 de janeiro de 2001. Aprova Regulamento Técnico sobre os padrões microbiológicos para alimentos. Diário Oficial da República Federativa do Brasil, Brasília, DF, 10 jan. 2001.

BRASIL. Projeto Manejo dos Recursos Naturais da Varzea - PROVARZEA. A vida da piramutaba e da dourada. Ibama: Brasília, 2005. 24 p.
CARRASCOSA, A. V.; CORNEJO, I. Cultivos iniciadores para productos cárnicos, curado Del jamón. Carnica 2000, v. 66, p. 36-40, 1989.

CARVALHO, P. R. Aditivos dos Alimentos. Revista LOGOS, n. 12, p. 57-69, 2005.

CHAWLA, S. P.; VENUGOPAL, V.; NAIR, P. M. Gelation proteins from washed muscle of threadfin bream (Nemipterus japonicus) under mild acidic conditions. Journal of Food Science, v. 61, n. 2, p. 362-366, 1996. http://dx.doi.org/10.1111/j.1365-2621.1996. tb14194.x

CUNHA NETO, A.; SILVA, C. G. M.; STAMFORD, T. L. M. Staphylococcus enterotoxigênicos em alimentos in natura e processados no estado de Pernambuco, Brasil. Ciência e Tecnologia de Alimentos, v. 22, n. 3, p. 263-271, 2002. http://dx.doi. org/10.1590/S0101-20612002000300012

FELTES, M. M. C. et al. Alternativas para a agregação de valor aos resíduos da industrialização de peixe. Revista Brasileira de Engenharia Agrícola e Ambiental, v. 14, n. 6, p. 669-677, 2010. http://dx.doi.org/10.1590/S1415-43662010000600014

GERMANO, P. M. L.; GERMANO, M. I. S. Higiene e vigilância sanitária de alimentos: qualidade das matérias-primas, doenças transmitidas por alimentos, treinamento de recursos humanos. São Paulo: Editora Varela, 2003. 665 p.

GODOY, L. C. et al. Análise sensorial de caldos e canjas elaborados com farinha de carcaças de peixe defumadas: aplicação na merenda escolar. Ciência e Tecnologia de Alimentos, v. 30, p. 86-89, 2010. Supplemento 1 .

GONÇALVES, A. A.; NOGUEIRA, W. M.; LOURENÇO, L. F. H. Aproveitamento do descarte do processamento da piramutaba (Brachyplatystoma vaillantii) e do camarão-rosa (Farfantepenaeus subtilis) na produção de salsicha sabor camarão. Boletim do Instituto de Pesca, v. 35, n. 4, p. 623-635, 2009.

INSTITUTO BRASILEIRO DO MEIO AMBIENTE E DOS RECURSOS NATURAIS - IBAMA. V Reunião do grupo permanente de estudos sobre a piramutaba. IBAMA. Brasília, 1999. n. 26, 92 p. (Coleção meio ambiente: Série estudos da pesca).

JESUS, R. S.; EDSON LESSI, L.; TENUTA-FILHO, A. Estabilidade química e microbiológica de "minced fish" de peixes amazônicos durante o congelamento. Ciência e Tecnologia de Alimentos, v. 21, n. 2, 2001.

KARTHIKEYAN, M.; DILEEP, A. O.; SHAMASUNDAR, B. A. Effect of water washing on the functional and rheological properties of proteins from threadfin bream (Nemipterus japonicus) meat. International Journal of Food Science and Technology, v. 41, p. 1002-1010, 2006. http://dx.doi.org/10.1111/j.13652621.2006.01122. $\mathrm{x}$

KUHN, C.R. et al. Avaliação reológica e físico-química da gelificação térmica do surimi de jundiá. Pesquisa Agropecuária Brasileira, v. 43 , n. 12 , p. 1793-1798, 2008. http://dx.doi.org/10.1590/S0100204X2008001200021

LIBRELATO, F. R.; LOPES-SHIKIDA, S. A. R. Segurança alimentar: um estudo multidisciplinar da qualidade do filé de tilápia comercializado no município de Toledo - PR. Informe Gepec, v. 9, n. 2, 2005.

MAGNANI, A. L. et al. Incidência de Salmonella e Escherichia coli em carne suína in natura e salame colonial, consumidos pela população de Chapecó - SC. Higiene Alimentar, v. 14, n. 73, p. 44-47, 2000.

MARTÍN-SANCHEZ, A. M. et al. Alternatives for Efficient and Sustainable Production of Surimi: A Review. Food Science and 
Food Safety, v. 8, p. 359-374, 2009. http://dx.doi.org/10.1111/j.15414337.2009.00087.x

MELLO, S. C. R. et al. Caracterização química e bacteriológica de polpa e surimi obtidos do espinhaço residual da filetagem de tilápia. Ciência Rural, v. 40, n. 3, p. 648-653, 2010. http://dx.doi. org/10.1590/S0103-84782010005000029

OGAWA, M. Y.; MAIA, E. L. Manual de pesca, Ciência e Tecnologia do Pescado. São Paulo: Varela, 1999. 429 p.

OLIVEIRA, N. M. S. et al. Avaliação físico-química de filés de tilápia (Oreochromis niloticus) submetidos à sanitização. Ciência e Tecnologia de Alimentos, v. 28, n. 1, p. 83-89, 2008. http://dx.doi. org/10.1590/S0101-20612008000100013

PEIXOTO, M. R. S.; SOUSA, C. L.; MOTA, E. S. Utilização de pescado (Macrodom ancylodon) de baixo valor comercial para obtenção de surimi empregado na elaboração de salsicha com sabor de camarão. Higiene Alimentar, v. 16, n. 99, 2002.

PINHEIRO, L. A; FRÉDOU, F. L. Caracterização geral da pesca industrial desembarcada no Estado do Pará. Revista Científica da UFPA, v. 4, 2004.

RIBEIRO, S. C. A. et al. Alteração da cor da carne de mapará (Hypophthalmus edentatus) desidratada osmoticamente e seca. Revista Brasileira de Produtos Agroindustriais, v. 9, n. 2, p. $125-135,2007$

SARMIENTO, A. M. L. Características microbiológicas, físico-químicas e sensoriais de filés de tilápias (Oreochromis niloticus) conservados em atmosferas modificadas sob refrigeração. 2006. 120 f. Dissertação (Mestrado em Ciência e Tecnologia de Alimentos)-Universidade Federal de Viçosa, Viçosa, 2006.

SILVA, M. H. M. Avaliação de fatores que influenciam na qualidade de um produto elaborado com resíduos comestíveis de peixes resultantes do processamento na indústria de pesca. 2006. Dissertação (Mestrado em Ciência e Tecnologia de Alimentos)Universidade Federal do Pará, Belém, 2006.

SIMÕES, M. R. et al. Composição físico-química, microbiológica e rendimento do filé de tilápia tailandesa (Oreochromis niloticus). Ciência e Tecnologia de Alimentos, v. 27, n. 3, p. 608-613, 2007. http://dx.doi.org/10.1590/S0101-20612007000300028

TEODORO, A. J.; ANDRADE, E. C. B.; MANO, S. B. Avaliação da utilização de embalagem em atmosfera modificada sobre a conservação de sardinhas (Sardinella brasiliensis). Ciência e Tecnologia de Alimentos, v. 27, n. 1, p. 158-161, 2007. http://dx.doi. org/10.1590/S0101-20612007000100028

VANDERZANT, C.; SPLITTSTOESSER, D. F. Compendium of methods for the microbiological examination of foods. 3rd. ed. Washington: American Public Health Association - APHA, 1992.

VAZ, S. K. Elaboração e caracterização de lingüiça fresca "tipo Toscana" de tilápia (Oreochromis niloticus). 2005. $113 \mathrm{f}$. Dissertação (Mestrado em Tecnologia de Alimentos)-Universidade Federal do Paraná, Curitiba, 2005. 